Bożena Chrostowska

https://doi.org/10.26881/pwe.2018.43.05

ORCID: 0000-0002-3397-6777

Uniwersytet Warmińsko-Mazurski w Olsztynie

b.chrostowska@uwm.edu.pl

\title{
Sharenting - skala i wielowymiarowość zjawiska (nierozważnego) ujawniania przez rodziców informacji o dzieciach w mediach społecznościowych
}

\begin{abstract}
Summary
Sharenting - the scale and multidimensionality of the phenomenon of the parents (inconsiderately) disclosing the information about their children in the social media

The scope of the article is to discuss the issue of the parents sharing the information about their children in social media. Basing on literature and researches review, the scale of sharenting phenomenon was introduced. Its different types were discussed and its chosen legal, ethical and social aspects were characterized. The risks (i.e. identity theft and exposing children to cyberviolence) and rewards (i.e. sharing the experience, seeking and providing support) of such parents' activity in the Internet were presented as well. Sharenting generates dilemmas connected with finding the balance between the parents' right to express freely and the child's right to have privacy, dignity and identity. There is a need of educational actions, directed to both parents and society, about the children's security and safety of their privacy in the Internet.
\end{abstract}

Keywords: parenting, (over)sharenting, child's image, child's privacy, digital footprints, social media

Słowa kluczowe: rodzicielstwo, (over)sharenting, wizerunek dziecka, prywatność dziecka, cyfrowe ślady, media społecznościowe

\section{Wprowadzenie}

Rewolucja cyfrowa zmieniła i zmienia nie tylko życie jednostek ale także grup, w których one funkcjonują. Społeczeństwo informacyjne wraz z nowymi technologiami, mediami czy coraz powszechniej dostępnym Internetem to środowisko naturalne dla wielu współczesnych rodzin (bo oczywiście są jednostki i środowiska wykluczone cyfrowo) (Karczmarzyk, Zbierzchowska 2016: 90). (Nad)aktywność bardzo młodych i młodych użytkowników sieci, w kontekście zagrożeń z niej płynących, jest przedmiotem namysłu i analiz badaczy (Tapscott 2010; Badanie nadużywania... 2012; Raport z badania... 2017; Wójcik 2017; Uszyńska-Jarmoc, Naruszewicz 2018) oraz rodziców. Bezpieczeństwo dzieci w Internecie stanowi również obiekt publicznej troski i podejmowane są różne działania 
mające na celu zwiększenie świadomości społecznej oraz edukację dzieci, ich opiekunów czy profesjonalistów w tym zakresie np. od 2005 roku realizowany jest w Polsce projekt Komisji Europejskiej pt. „Safer Internet”.

Don Tapscott w książce opublikowanej w 2009 roku, entuzjastycznie opisując cechy i potencjał pokolenia sieci, ostrzegał jednocześnie młodych ludzi przed ujawnianiem informacji na temat swego życia osobistego. Autor wręcz podkreślał, że martwi go kwestia ochrony prywatności i stwierdza, że reprezentanci pokolenia sieci „muszą się ocknąć i przemyśleć, gdzie wyznaczyć granicę odkrywania swojej prywatności, by nie ujawnić czegoś, co w przyszłości woleliby zachować w tajemnicy" (Tapscott 2010: 47). Obecnie, użytkownikami sieci są jednak nie tylko przedstawiciele młodego pokolenia, ale również ich rodzice (z których część stanowi zapewne, opisywaną przez Tapscotta, net generation). Działalność tej drugiej grupy w kontekście dzielenia się w cyberprzestrzeni informacjami o wyglądzie, zachowaniach i rozwoju swoich dzieci, jest rzadziej monitorowana i poświęca się jej wciąż stosunkowo niewiele uwagi (Ammari i in. 2015; Brosch 2017; Steinberg 2017b), choć rośnie zainteresowanie tym zjawiskiem, w tym w Polsce (Brosch 2016; Kot 2016; Brosch 2017; Błasiak 2018).

Sharenting - bo o nim mowa - powstało z połączenia dwóch angielskich słów: parenting - oznaczającego rodzicielstwo (w sensie pełnienia rodzicielskiej roli) oraz sharing oznaczającego czynność rozpowszechniania. Pojęcie to odnosi się do zaangażowania rodziców głównie w przestrzeni mediów społecznościowych polegającego na regularnym zamieszczaniu szczegółowych informacji (zdjęć, filmików i innych treści) o swoich dzieciach (Keith, Steinberg 2017: 413). Sharenting odróżnia się od oversharentingu oznaczającego ekstremalną aktywność rodziców w tym obszarze oraz troll parentingu, oznaczającego dzielenie się treściami, które wprost kompromitują dzieci lub pokazują trudne dla nich momenty (Majak 2013; Keith, Steinberg 2017: 413). Jak wynika ze zrealizowanych (a omawianych w dalszej części artykułu) badań skala zjawiska znacznie wykracza poza, nie wzbudzające na ogół kontrowersji, dzielenie się ogólnymi informacjami o dziecku, a badacze coraz częściej dyskutują o motywacji oraz konsekwencjach tego typu zachowań (szczególnie w kontekście dobrostanu dzieci). Niewiele o tych ostatnich wiadomo, bowiem dzieci urodzone i dorastające w erze mediów społecznościowych wkraczają dopiero W wiek nastoletni. $\mathrm{W}$ debacie na temat sharentingu szczególne miejsce zajmuje również namysł nad relacją pomiędzy prawem rodzica do swobodnej ekspresji a prawem dziecka do zachowania swej prywatności, godności i tożsamości oraz działaniami edukacyjnymi dedykowanymi rodzicom i profesjonalistom mającymi na celu zachowanie balansu w realizacji wspomnianych praw. Celem artykułu jest przybliżenie głównych wątków tej dyskusji, toczącej się przede wszystkim na łamach obcojęzycznej literatury.

\section{Skala zjawiska sharentingu}

Jedno z ciekawszych przedsięwzięć badawczych, którego przedmiotem była wielowymiarowa analiza aktywności rodziców w mediach społecznościowych, zostało zrealizowane 
w USA w 2014 roku przez Pew Research Center wśród reprezentatywnej próby dorosłych Amerykanów (2003 osoby), w tym rodziców dzieci poniżej 18 roku życia (494), z których część (366) stanowili rodzice - użytkownicy mediów społecznościowych. Z uzyskanych danych wynika, że $75 \%$ rodziców korzystających z internetu, korzystało z różnorodnych mediów społecznościowych, a najbardziej popularnym wśród rodziców użytkowników internetu był portal społecznościowy Fb (74\%). Rodzice - użytkownicy Fb tworzą grupę osób mocno weń zaangażowanych i 75\% sprawdza go codziennie, w tym ponad połowa (51\%) kilka razy dziennie (więcej matek niż ojców - 56\% vs 43\%) aktywność ta oraz jej częstotliwość różni się od aktywności osób niebędących rodzicami, a różnica ta jest istotna statystycznie (wśród nie-rodziców 67\% loguje się codziennie, w tym $42 \%$ kilka razy dziennie). Podczas gdy 79\% badanych rodziców-użytkowników mediów społecznościowych postrzega je jako źródło cennych informacji, nieco mniej, bo 59\% (w ostatnich 30 dniach od daty badania), znalazło przydatne informacje dotyczące rodzicielstwa, $42 \%$ zdeklarowało, że otrzymało wsparcie ze swoich internetowych sieci związane z pełnieniem przez siebie roli rodzica, a $31 \%$ zadało pytanie związane $\mathrm{z}$ ich rodzicielstwem. $\mathrm{Z}$ raportu wynika również, że matki nieco częściej używają mediów społecznościowych jako zasobu dla rodziców niż ojcowie (Duggan i in. 2015)

Rodzice to zatem osoby obecne i aktywne w internecie, a spora cześć z nich w mediach społecznościowych. Nawet jeśli nie wszyscy deklarują, że stanowią one dla nich miejsce do szukania informacji na temat rodzicielstwa i wymiany doświadczeń rodzicielskich nie oznacza to automatycznie, że nie dzielą się informacjami o swoich dzieciach i ich zdjęciami. Powszechność sharentingu dokumentują wyniki różnorodnych badań. Jedno z nich, zrealizowane przez AVG Technologies w 2010 roku wśród 2200 matek dzieci poniżej 2 roku życia, aktywnych w internecie z USA, wybranych krajów UE, Australii, Nowej Zelandii i Japonii donoszą o $81 \%$ dzieci poniżej 2 roku życia mających cyfrowy ślad w postaci zdjęcia pozostawionego przez swoich rodziców (w USA liczba ta wynosiła najwięcej bo $92 \%$, średnia dla państw UE biorących udział w badaniu wyniosła 73\%), zaś średnia wieku cyfrowych narodzin dziecka wynosiła w chwili badania 6 miesięcy, a 5\% miało swój profil społecznościowy. Uzyskane wyniki pokazują również inne zjawisko - cześć dzieci (23\%) rodzi się cyfrowo, nim fizycznie przyjdzie na świat. Dzieje się to za sprawą umieszczania w sieci przez rodziców ich ultrasonograficznych zdjęć (Digital Birth... 2010).

Interesujące jest również to jak rodzice wypowiadają się o korzyściach i obawach związanych z dzieleniem się informacjami na temat rodzicielstwa w mediach społecznościowych. Danych na ten temat dostarczają badania zrealizowane w 2014 roku w USA, przez C.S. Mott Children's Hospital National Poll on Children's Health na reprezentatywnej próbie 569 rodziców dzieci w wieku $0-4$ lata. W świetle uzyskanych wyników większość badanych rodziców ( $84 \%$ matek, $70 \%$ ojców) deklarowało korzystanie z mediów społecznościowych takich jak Fb, blogi i fora internetowe. Rodzice zapytani o obawy wskazywali, iż boją się, że ktoś przez ich aktywność wejdzie w posiadanie prywatnych informacji o ich dziecku (68\%), wykorzysta jego zdjęcia (67\%), zaś 52\% badanych wyraziło lęk, że kiedy ich dzieci dorosną mogą poczuć się zakłopotane tym, co jako rodzice 
ujawnili na ich temat. Interesującą kwestią jest również postrzeganie przez badanych rodziców aktywności innych rodziców w kontekście oversharentingu. Większość ankietowanych korzystających z mediów społecznościowych (74\%) zna innego rodzica, który ich zdaniem udostępnił zbyt wiele informacji o swoim dziecku, w tym podał krepujące fakty na jego temat $(56 \%)$, dane osobowe ułatwiające jego lokalizację (51\%) oraz udostępnił nieodpowiednie zdjęcia dziecka (27\%) (Parents on social... 2015).

\section{Wielowymiarowość sharentingu}

Już ten syntetyczny, bo ograniczony ramami artykułu, przegląd wyników badań pokazuje, że mamy do czynienia z powszechnym zjawiskiem a dokumentowanie online życia dzieci stało się niemalże normą społeczną (Wayne 2016). Niektórzy badacze mówią o sharentingu wręcz jako o nowym wymiarze rodzicielstwa, w którym rodzice poszukują spełnienia oraz szukają wzorców swych ról w wirtualnej sieci kontaktów społecznych, coraz bardziej izolując się od bliskich struktur społecznych (Brosch 2017: 380). Warto przyjrzeć się zatem różnym wymiarom tego zjawiska. Jednym z nich jest aspekt prawno-etyczny. Publikowanie przez rodziców zdjęć dziecka łączy się z dysponowaniem jego wizerunkiem. W świetle polskich przepisów wizerunek jest dobrem osobistym człowieka, które podlega ochronie przepisów prawa cywilnego oraz prawa autorskiego. W ustawie o prawie autorskim i prawach pokrewnych zaznacza się, iż rozpowszechnianie wizerunku wymaga zezwolenia osoby na nim przedstawionej (Dz.U. $1994 \mathrm{Nr} 24$ poz. 83, art. 81.). Z uwagi na to, że dziecko nie posiada zdolności do czynności prawnych, to opiekunowie dbają o jego dobro do osiągnięcia przez nie pełnoletniości. Zatem to rodzice dysponują wizerunkiem dziecka i to oni udzielają zgody na jego udostępnienie. Sąd może interweniować, gdy przedstawiony wizerunek uwłacza godności dziecka, wskazuje na możliwość popełnienia przestępstwa lub uzyskania przez rodzica znacznych korzyści majątkowych kosztem dobra dziecka oraz gdy kwestia wykorzystania wizerunku zostanie uznana za istotne sprawy dziecka (Ryńska 2015). Konsekwencje i uwarunkowania prawne wzmacniają więc w tym przypadku naturalną rolę rodziców jako strażników dobra dziecka, w tym protektorów jego cyfrowej tożsamości, z drugiej strony, czynią z nich dysponentów spraw dziecka. W tej optyce prawo rodziców do dysponowania wizerunkiem dziecka, czy szerzej wolność dzielenia się różnymi informacjami (ale także prawo do ekspresji), przeciwstawiane jest prawu dzieci do prywatności, godności i tożsamości (wynikających choćby z zapisów Konwencji o Prawach Dziecka). Takie zderzenie i rodzące się na jego styku napięcie generuje pytania o granicę dzielenia się informacjami, na której kończy się tożsamość rodzica a zaczyna się tożsamość dziecka, o prawo dziecka do definiowania i decydowania o własnej tożsamości a nie przyjmowania wykreowanej cyfrowo przez rodziców, o to, czym właściwie rodzic, snując cyfrową narrację o dziecku, może się podzielić z innymi. Dzieci mogą też nie zgadzać się z decyzją rodziców dotyczącą dzielenia się ich wizerunkiem czy innymi informacjami o nich (zarówno negatywnymi, jak i pozytywnymi). Podczas gdy rodzice mogą ustanawiać własne parametry udostępniania, dzieci nie mają takiej kontroli nad swoimi „cyfrowymi 
śladami" zostawianymi przez ich dorosłych opiekunów (Steinberg 2017; Keith, Steinberg 2017; Blum-Rose, Livingstone 2017). Niektórzy badacze podkreślając trwałość pozostawianych przez rodziców cyfrowych śladów mówią wręcz o cyfrowym tatuażu (za: Blum-Ross 2015) pozostawionym na wizerunku (tożsamości?) dziecka, zanim będzie ono mogło samodzielnie decydować o tym, czy i co udostępniać na swój temat w wirtualnym świecie. Inni wskazują, że „sharenting może nieumyślnie odebrać dziecku nieodłączne prawo do decydowania o swojej tożsamości" (Keith, Steinberg 2017: 413)

Zjawisko dzielenia się zdjęciami rodzinnymi, w tym dzieci, istnieje odkąd wymyślono aparat fotograficzny. Odbitki papierowe krążyły jednak zazwyczaj w wąskim kręgu odbiorców, znanych najczęściej rodzinie. Fotografia cyfrowa oraz rozwój technologii spowodował, że zamieszczane w internecie zdjęcia mogą dotrzeć do wielu osób, a część z nich może być zupełnie nieznana rodzicom. Umieszczenie zdjęcia (czy innej informacji o dziecku) w sieci powoduje, że rodzic traci nad nim kontrolę, tak w zakresie tego, kim jest odbiorca udostępnionych treści, jak i tego, do jakich celów mogą być one użyte (Brosch 2017: 380). Media społecznościowe to nie jedyne miejsce publikowania zdjęć dzieci w sieci. Popularnością wśród rodziców cieszą się blogi (w tym parentingowe) oraz repozytoria fotograficzne. Rozpowszechnianiu zdjęć towarzyszą zazwyczaj komentarze, podpisy czy informacje nie tylko związane z okolicznością ich zarejestrowania, ale ujawniające dane dziecka jak np. imię i nazwisko, wiek, data urodzin czy dotyczące jego sytuacji zdrowotnej, szkolnej, postępów i trudności, relacji z innymi oraz szereg innych (Wojtasik 2014: 58; Brosch 2016: 229-230). O ile w dobie popularności internetu, kiedy to w naturalny sposób przesuwają się granice prywatności, udostępnianie kilku ogólnych informacji o dziecku w mediach społecznościowych nie budzi obaw, to częsta i prowadzona na dużą skalę publikacja zdjęć i treści dotyczących dzieci staje się coraz bardziej problematyczna i wywołuje dyskusje wśród komentatorów i badaczy tego zjawiska (Brosch 2016, 2017; Steinberg 2017). Jego etyczno-prawny aspekt wzmacnia również istniejący i dość popularny wśród rodziców oraz innych użytkowników sieci (choć nieznana jest dokładnie skala tego zjawiska) tzw. troll parenting. Oprócz dokumentowania chwil z życia dziecka, opisywania wyzwań, jakie stawia jego wychowanie oraz szukania w związku z tym wsparcia, rodzice są aktywni w innym wymiarze. Część z nich nagrywa i umieszcza w sieci filmy czy zdjęcia, które przedstawiają dzieci w „zabawnych”, ale ośmieszających je i często kontrowersyjnych sytuacjach. Np. w badaniach A. Brosch (2017) były to zdjęcia siedzącego nago na nocniku i płaczącego chłopczyka czy trzymającej butelkę wina dziewczynki. Istnieją również serwisy internetowe, w których można zamieszczać „śmieszne" zdjęcia dzieci. Przykładem takiego miejsca w sieci jest strona Reasons My Son is Crying, na której rodzice zamieszczają zdjęcia swych płaczących dzieci, dopisując do nich „odpowiedni” komentarz np. „Nie pozwoliłam im zjeść mojego skierowania do psychiatry”, „Poprosiłam ją, by przestała wkładać rękę do ubikacji”, „Pękł jej balonik"(Majak 2013). Rodzice w sieci wykazują się swego rodzaju pomysłowością i oprócz uwieczniania oraz udostępniania „naturalnych" sytuacji z życia, umieszczają zdjęcia (czy filmiki) dzieci specjalnie „ustylizowanych” tak, by wywołać w odbiorcy rozbawienie, np. 
dziecko ubrane w koszulkę z napisem „Świętego Mikołaja nie ma, ale i tak nie umiem jeszcze czytać" czy przebranych, jak np. chłopiec w różowy strój baletnicy ze smoczkiem w ustach (Kiebus 2013). Miejscem w sieci, które obfituje w „zabawne” filmiki z udziałem dzieci, których autorami są ich rodzice jest również kanał you tube.

Oddzielną kategorię zdjęć dzieci udostępnianych przez rodziców w internecie stanowią te, na których występują one nago (lub w bieliźnie) podczas wykonywania czynności higienicznych, w czasie kąpieli, wakacji. Ich upowszechnianie, poza kwestiami etycznymi i innymi problematycznymi zagadnieniami omawianymi wyżej, może stanowić realne niebezpieczeństwo wykorzystania przez osoby o skłonnościach pedofilskich. W jednym z badań zrealizowanych przez rząd australijski odkryto, że połowa zdjęć dzieci udostępnionych na stronach pedofilskich pochodziła ze stron mediów społecznościowych (Battersby 2015). Innym zagrożeniem, na które wskazuje $€$. Wojtasik, jest to, że tego typu wizerunki, kiedy trafią w ręce rówieśników czy znajomych dziecka, mogą zostać wykorzystane przeciwko niemu (narazić na kpiny, zawstydzić) czy zostać użyte w procesie cyberprzemocy, doprowadzając do poważnych konsekwencji (Tenże 2017: 59). Z badań A. Brosch zrealizowanych w 2015 roku wśród 168 rodziców użytkowników Fb, wynika, że 113 badanych $(67,3 \%)$ udostępniło na swoich profilach przynajmniej jedno zdjęcie, które zostało uznane za niewłaściwe czy zawstydzające. Najbardziej popularnym typem zdjęć w tej kategorii były ukazujące dzieci nagie lub półnagie. Były to najczęściej wizerunki dzieci poniżej 3 roku życia zrobione w czasie kąpieli oraz na plaży (Brosch 2016: 230-231).

Inne ryzyka związane z sharentingiem, na które wskazują komentatorzy zjawiska dotyczą kradzieży tożsamości dziecka oraz możliwości ustalenia lokalizacji dziecka, a także innych danych ułatwiających jego rozpoznanie. Udostępnianie w sieci zdjęcia dzieci, szczególnie z telefonów komórkowych (typu smartfon), mogą zawierać tzw. meta dane dotyczące szczegółów lokalizacji oraz inne, pozwalające na identyfikację fotografowanego (Blum-Ross 2015). Natomiast kradzież tożsamości dziecka (tzw. digital kidnapping) polega na grabieży zdjęcia dziecka, np. z cudzego profilu w mediach społecznościowych, i udostępnianiu go przez internet. Ma to różne oblicza, np. ktoś wykorzystując zdjęcie cudzego dziecka, prezentuje je jako własne, używa skradzionego wizerunku dziecka w celach komercyjnych czy umieszcza w portalach społecznościowych, by posłużyć się nim do realizacji różnych fantazji, w tym seksualnych. Przykładem tej ostatniej aktywności jest tzw. baby role play na Instagramie. Użytkownik umieszcza zdjęcie nieznanego sobie dziecka (nadając mu wybrane przez siebie imię, opisując co lubi, a czego nie) informując, że jest gotowe do adopcji. Udostępniając skradziony wizerunek, sam zaczyna odgrywać rolę dziecka (ze zdjęcia) bądź jego rodzica. Inni użytkownicy „adoptują sierotę” wcielając się w wybraną przez siebie rolę poprzez komentowanie zdjęcia i wysyłanie bezpośrednich wiadomości, na które udostępniający może odpowiadać. A. Schroeder wskazuje na trzy funkcjonujące $\mathrm{w}$ społeczności baby role play wątki narracyjne. Pierwszy dotyczy osób, które wirtualnie adoptując, „,wykonują" normalne rodzicielskie zadania, okazując empatię wobec swych wirtualnych dzieci, kolejny tych, którzy w swej roli (rodzica lub dziecka) eksponują nadużywanie fizyczne oraz takich, których narracja realizuje ich „brudne” lub 
seksualne, przemocowe fantazje. W tym przypadku wizerunek dziecka nie jest eksploatujący je sam w sobie (jak np. ma to miejsce w aktywności troll parentingowej), rekontekstualizują go natomiast, poprzez swoje narracje, roleplayerzy (Schroeder 2017). Na Instagramie w 2015 roku było ponad 55 tysięcy zdjęć otagowanych znacznikami \#babyrp, \#adoptionrp, \#orphanrp ułatwiającymi użytkownikom odszukanie zdjęć służących do baby role play (Friedman 2015).

Sharenting to nie wyłącznie ryzyka i dylematy, jakie ze sobą niesie, bowiem aktywność rodziców w mediach społecznościowych analizowana jest również pod kątem oferowanych korzyści. Nie tylko chodzi bowiem o to, że pozwala on na utrzymywanie kontaktów z rodziną czy znajomymi, ale, jak pokazały przedstawione wcześniej wyniki badań, umożliwia dzielenie się swymi rodzicielskimi doświadczeniami, radościami oraz poszukiwanie i udzielanie wsparcia. Dla części rodziców taka aktywność to główne źródło wiedzy o rodzicielstwie (Parents on social... 2015). W przypadku opiekunów dzieci z różnymi chorobami czy niepełnosprawnością to źródło czasem jedynego wsparcia (wobec niewydolności wsparcia instytucjonalnego), a także wiedzy specjalistycznej, bo płynącej z doświadczenia innych rodziców i ich znajomości np. rynku usług specjalistycznych, możliwości ich pozyskiwania, informacji o polecanych w środowisku lokalnym profesjonalistach (Hamm i in. 2013; Jacobs i in. 2016). W takim kontekście sharenting może być również wykorzystywany przez rodziców jako narzędzie rzecznictwa w problemach dzieci (Keith, Steinberg 2017: 413). Badacze wskazują również na funkcję sharentingu w kształtowaniu i utrzymaniu kapitału społecznego współczesnych rodziców, szczególnie tych, dla których rodzicielstwo wiąże się z ograniczeniami w bezpośrednich kontaktach interpersonalnych i/lub żyjących z dala od bardziej tradycyjnych grup wsparcia (jak np. rodzina wielopokoleniowa). $\mathrm{W}$ tym przypadku media społecznościowe mogą pełnić rolę „cyfrowej wioski” oferującej zastępczą/alternatywną strukturę wsparcia (w myśl afrykańskiego przysłowia, iż potrzeba całej wsi, by wychować dziecko). Rodzice przez zamieszczanie informacji i zdjęć swoich dzieci angażują innych użytkowników w społeczne interakcje (Martindale 2014; Brosch 2017: 382). Ponadto otrzymując, często pozytywną informację zwrotną (w postaci polubień posta, jego udostępnień czy aprobującego komentarza), czują się wspierani w swej decyzji, by dzielić się informacjami o swoim życiu rodzinnym, w tym dziecku, a pośrednio tym, jakimi są rodzicami. Można przypuszczać zatem, że sharenting pełni funkcję poszukiwania i pozyskiwania społecznej aprobaty (Steinberg 2018b: 846). A. Brosch wskazuje również na związek sharentingu z mechanizmem porównań społecznych, w ramach którego działania rodziców w mediach społecznościowych mogą wynikać z potrzeby zbierania informacji o innych rodzicach i ich działaniach, by przez proces porównywania określić czy ocenić siebie. Badaczka zauważa, że poprzez sharenting rodzice mogą „deklarować” swoją gotowość wypełniania rodzicielskich zadań i zdawać relację z ich realizacji (Brosch 2016: 232).

Podsumowując, chociaż sharenting może być postrzegany jako źródło wielu korzyści dla rodziców i niewątpliwe nim jest, problematyczny staje się wówczas, gdy rodzice przekraczają granicę, którą stanowi dobro dziecka czy jego prawo do decydowania o własnej 
tożsamości. Jak wskazuje analiza zagrożeń i dylematów etyczno-prawnych wynikających z takiej aktywności rodziców, mamy do czynienia ze zjawiskiem o poważnych konsekwencjach dla dobrostanu dzieci.

\section{Zakończenie}

Co roku wzrasta liczba użytkowników mediów społecznościowych i można spodziewać się, że sharenting (oraz pokrewne mu oversharentig czy troll parenting) będzie nadal powszechną praktyką wśród wielu rodziców, w tym młodych, dla których funkcjonowanie i aktywność w cyberprzestrzeni jest naturalną częścią ich życia (Livingstone i in. 2018: 6). Wśród badaczy i komentatorów tego zjawiska budzi ono niepokój i obawy choćby ze względu na wskazane kontrowersje w płaszczyźnie utrzymania równowagi pomiędzy prawem i potrzebami rodzica do swobodnej ekspresji, poszukiwania wsparcia, komunikacji a prawem dziecka do poszanowania jego prywatności, godności i (kreowania) tożsamości. Trudno jest również przewidywać z całą pewnością różnorakie konsekwencje, jakie będą ponosić dorastające dzieci, a w przyszłości osoby dorosłe w związku z posiadaniem cyfrowych śladów (tatuaży), których nie są autorami czy cyfrowej tożsamości, zdefiniowanej przez rodziców, a nie przez samodzielne wybory. Nie bez znaczenia pozostają też inne zagrożenia, które zostały przywołane w artykule (kradzież tożsamości, wykorzystanie wizerunku dziecka przez strony pedofilskie, publiczne wyśmiewanie dziecka). Eksperci od mediów społecznościowych ostrzegają, że to, co rodzice opublikują w sieci będzie miało w przyszłości wpływ na szanse życiowe dziecka, np. na dostanie się na określone studia czy uzyskanie wymarzonego stanowiska w pracy. Najnowsze rozwiązania oferowane przez niektóre media społecznościowe pozwalają bowiem za pomocą zawansowanych technicznie wyszukiwarek przeszukiwać zasoby sieci i zbierać informacje o danej osobie. Cyfrowe ślady z dzieciństwa stają się elementem składowym profilu psychologicznego, który może być wykorzystany przez uczelnie czy pracodawców w procesie rekrutacji. Co więcej pojawiają się obecnie w przestrzeni społecznej specjalne agencje wyszukujące w internecie informacji o wybranych osobach. Trudno na ten moment przewidzieć przyszłość takich praktyk, ale jak wskazuje $€$. Wojtasik - technologia może zaskoczyć i osoby obecne w sieci od urodzenia mogą znaleźć się w kłopotliwym położeniu (Wojtasik 2014: 58).

Dzieci wzrastające w dobie powszechności korzystania z mediów społecznościowych wkraczają dopiero w wiek nastoletni. Co jakiś czas media donoszą jednak o wyrokach sądowych za publikowanie w sieci przez rodziców zdjęć dzieci, których nie tylko pozywają ich partnerzy, ale i własne potomstwo. Niektóre kraje - jak Francja - unormowały przepisy dotyczące ochrony wizerunku dzieci, które po osiągnięciu pełnoletniości mogą pozwać swych opiekunów za publikowanie zdjęć, na których występują bez ich zgody, za co grożą wysokie kary pieniężne czy pozbawienie wolności do jednego roku (Wójtowicz 2017).

$Z$ drugiej strony, współczesne rodziny (zwłaszcza, że coraz częściej tworzą je reprezentanci pokolenia sieci) będące elementem społeczeństwa cyfrowego, korzystają z możliwości, które niesie za sobą aktywność w Internecie. Rodzicielstwo staje się doświadczeniem 
podzielanym online. Jak pokazały wyniki przytoczonych badań wiąże się ono, w przypadku sporej grupy rodziców-sharentsów, z naruszaniem prawa dzieci do prywatności. Implikuje to pytania o działania, które muszą podjąć społeczeństwa w zakresie monitorowania i ochrony tego prawa. Oprócz wprowadzania rozwiązań legislacyjnych, jak tych wdrożonych we Francji czy wynikających z unijnego rozporządzenia RODO (prawo do bycia zapomnianym) ważna jest edukacja rodziców, profesjonalistów ich wspierających, społeczności, obejmująca informacje o potencjalnych problemach związanych z kwestią (i prawem do) prywatności dzieci oraz zagrożeniach bezpieczeństwa związanych z udostępnianiem on-line informacji o nich. W USA wypracowano rozwiązanie określone przez jego autorkę jako model edukacji ukierunkowany na dzieci oparty na zdrowiu publicznym, respektujący z jednej strony prawo dzieci do prywatności, z drugiej zaś uznający prawo rodzica do swobodnych wypowiedzi. Twórczyni rekomenduje rozpowszechnianie go wśród rodziców, nauczycieli, praktyków, decydentów i w mediach (Steinberg 2017b). W Polsce w latach 2012-2013 Fundacja Dzieci Niczyje (obecnie Fundacja Dajemy Dzieciom Siłę) zrealizowała kampanię społeczną skierowaną do rodziców „Pomyśl, zanim wrzucisz", której celem było zwrócenie uwagi na problem bezrefleksyjnego udostępniania zdjęć dzieci przez ich rodziców oraz kwestię ochrony ich prywatności w internecie. Przy okazji kampanii wydano poradnik dla rodziców. Inną inicjatywą realizowaną w ramach wspominanego programu Safer Internet było opublikowanie w 2014 roku opracowania w formie pdf pt. „Bezpieczeństwo dzieci online. Kompendium dla rodziców i profesjonalistów", w którym jeden z rozdziałów poświęcono nierozważnemu publikowaniu wizerunku dzieci przez dorosłych. Jeśli chodzi o zainteresowanie problematyką sharentingu w Polsce, to ukazało się kilka artykułów naukowych na ten temat, natomiast zagadnienie to nie wydaje się leżeć w kręgu zainteresowań decydentów, czego wyrazem w innych krajach (np. USA czy Wielkiej Brytanii) jest monitorowanie zjawiska poprzez choćby zlecanie badań na reprezentatywnych próbach rodziców i szerokie nagłaśnianie tematu w mediach. Wydaje się, że trzeba pilnie podjąć takie starania, bowiem jak twierdzi S. Steinberg „rodzice często wtrącają się w cyfrową tożsamość dziecka, nie dlatego, że są złośliwi, ale dlatego, że nie uznali jeszcze po prostu jej znaczenia" (Steinberg 2017a).

\section{Literatura}

Ammari T., Kumar P., Lampe C., Schoeneback S. (2015), Managing Children's Online Identities: How Parents Decide what to Disclose about their Children Online.

https://yardi.people.si.umich.edu/pubs/Schoenebeck_ManagingChildrensIdentities15.pdf, 8.09.2018.

Badanie nadużywania internetu przez młodzież w Polsce (2012). Warszawa, Fundacja Dzieci Niczyje. https://www.saferinternet.pl/pobierz.php?i=4\&hash=3e67, 9.09.2018.

Battersby L. (2015), Millions of social media photos found on child exploitation sharing sites. "The Sydney Morning Herald”. https://www.smh.com.au/national/millions-of-social-media-photosfound-on-child-exploitation-sharing-sites-20150929-gjxe55.html, 10.09.2018. 
Blum-Ross A. (2015), 'Sharenting:' parent bloggers and managing children's digital footprints. Parenting for a digital future. http://eprints.lse.ac.uk/76347/, 9.09.2018.

Blum-Ross A., Livingstone S. (2017), Sharenting: parent blogging and the boundaries of the digital self. "Popular Communication", 15 (2).

Błasiak A. (2018), Sharenting - współczesna forma rodzicielskiej narracji. „Horyzonty Wychowania" 17 (42).

Brosch A. (2017), Sharenting - nowy wymiar rodzicielstwa? W: H. Krauze-Sikorska, M. Klichowski (red.), Świat małego dziecka. Przestrzeń instytucji, cyberprzestrzeń i inne przestrzenie dzieciństwa. Poznań, Wydawnictwo Naukowe UAM.

Brosch A. (2016), When the child is Born in the Internet: Sharenting as a Growing Trend Among Parents on Facebook. "The New Educational Review", 43 (1).

Digital Birth: Welcome to the Online World 2010. https://www.businesswire.com/news/ home/20101006006722/en/Digital-Birth-Online-World, 11.09.2018.

Duggan M., Lenhart A., Lampe C., Ellison N.B. (2015), Parents on social media. Pew Research Center. http://www.pewinternet.org/2015/07/16/parents-and-social-media/, 9,09.2018.

Friedman M. (2015), “Digital Kidnapping” Is a Real (and Creepy) Threat When You Post Your Children's Photos Online. 10.09.2018.

Hamm M.P., Chisholm A., Shulhan J., Milne A., Scott S.D., Given M.G., Hartling L. (2013), Social media use among patients and caregivers: a scoping review. "BMJ Open", 3.

Jacobs R., Boyd L., Brennan K., Sinha C.K., Giuliani S. (2016), The importance of social media for patients and families affected by congenital anomalies: A Facebook cross-sectional analysis and user survey. "Journal of Pediatric Surgery", 51 (11).

Karczmarzyk M.A., Zbierzchowska A. (2016), Wizerunek rodziny polskiej w Internecie - analiza semiotyczna wybranych forów dyskusyjnych. „Wychowanie w Rodzinie”, XIII (1).

Keith B.E., Steinberg S. (2017), Parental sharing on the Internet. Child privacy in the age of social media and the pediatrician's role. „JAMA Pediatrics” 171 (5).

Kiebus M. (2013), 28 Parents Who Are Trolls At Heart. What's the use of having children unless you can mess with them constantly? https://www.buzzfeed.com/mjkiebus/parents-who-are-trolls-atheart-6ygq, 11.09.2018.

Kot M. (2016), Prywatność dziecka w Internecie a rozpowszechnienie jego wizerunku przez rodziców prowadzacych wideoblogi. „Kwartalnik Nauk o Mediach”, 3.

Livingstone S., Blum - Ross A., Zhang D. (2018), What do parents think, and do, about their children's online privacy? Parenting for a Digital Future: Survey Report 3. Department of Media and Communication.

http://eprints.1se.ac.uk/87954/1/Livingstone_Parenting\%20Digital\%20Survey\%20Report\%203_ Published.pdf, 12.09.2018.

Majak K. (2013), Troll Parenting, czyli rodzice wyśmiewają własne dzieci w internecie. http://natemat.pl/60525,troll-parenting-czyli-rodzice-wysmiewaja-wlasne-dzieci-w-internecie, 9.09.2018.

Martindale S. (2014), Obsessive 'sharenting' could be more than digital narcissism.

https://theconversation.com/obsessive-sharenting-could-be-more-than-digital-narcissism-30331, 12.09.2018.

McCarthy C. (2017), Sharenting: 5 questions to ask before you post. https://www.healthychildren. org/English/family-life/Media/Pages/Sharenting-5-Questions-to-Ask-Before-You-Post.aspx, 12.09.2018. 
Parents on Social Media: Likes and Dislikes of Sharenting (2015), „C.S. Mott Children's Hospital National Poll on Children's Health” 23 (2). https://mottpoll.org/reports-surveys/parents-socialmedia-likes-and-dislikes-sharenting, 9.09.2018.

Raport z badania. Nastolatki 3.0. (2017), Warszawa, NASK Instytut Badawczy.

Ryńska N. (2015), O publikacji zdjęć dziecka na facebooku decyduja oboje rodzice. http://prawo. gazetaprawna.pl/artykuly/867782,o-publikacji-zdjec-dziecka-na-facebooku-decyduja-obojerodzice.html, 10.09.2018.

Schroeder A. (2017), The horrifying, abusive world of baby roleplaying on Instagram. https://www. dailydot.com/irl/instagram-baby-roleplaying-rp-finding/, 12.09.2018

Steinberg S. (2017a), Sharenting - in whose interests?. http://blogs.lse.ac.uk/parenting4digitalfuture/2017/05/17/sharenting-in-whose-interests/, 9.09.2018

Steinberg S. (2017b), Sharenting: children's privacy in the age of social media. https://scholarship. law.ufl.edu/facultypub/779/, 9.09.2018.

Tapscott D. (2010), Cyfrowa dorosłość. Jak pokolenie sieci zmienia nasz świat. Warszawa, Wydawnictwa Akademickie i Profesjonalne.

Uszyńska-Jarmoc J., Naruszewicz A. (2018), Dziecięce rozumienie cyberprzestrzeni i zagrożeń z nia zwiazanych. „Problemy Wczesnej Edukacji”, 2 (41).

Wojtasik Ł. (2014), Nierozważne publikowanie wizerunku dziecka przez dorostych. W: A. Wrzesień-Gandolfo (red.), Bezpieczeństwo dzieci online. Kompendium dla rodziców, nauczycieli i profesjonalistów. Warszawa, Polskie Centrum Programu Safer Internet.

Wójcik S. (2017), Zagrożenia dzieci i młodzieży w internecie. „Dziecko Krzywdzone. Teoria, Badania, Praktyka", 16 (1).

Wójtowicz P. (2017), Pierwszy wyrok za opublikowanie w sieci zdjęcia dziecka - precedens czy burza w szklance wody?.https://kobieta.onet.pl/dziecko/male-dziecko/pierwszy-wyrok-zaopublikowanie-w-sieci-zdjecia-dziecka-precedens-czy-burza-w/clp4bj0, 7.09.2018. 